\title{
Eco-Social Enterprise's Innovation in the Human Society
}

\author{
Chin-Ken Lin1, Ariana Chang1, Jer-San Hu² \\ ${ }^{1} \mathrm{PhD}$ Program in Business Administration, College of Management, Fu Jen Catholic University, Taiwan \\ ${ }^{2}$ Department of Business Administration, Fu Jen Catholic University, Taiwan \\ Email: holos.lin@msa.hinet.net
}

Received 9 December 2015; accepted 25 December 2015; published 28 December 2015

Copyright (C) 2015 by authors and Scientific Research Publishing Inc.

This work is licensed under the Creative Commons Attribution International License (CC BY).

http://creativecommons.org/licenses/by/4.0/

(c) (i) Open Access

\section{Abstract}

The aim of this study is to reframe the eco-social enterprise from different types of societal innovations in the human society. This paper argues and analyzes for the following statements. First, a three-layer cake with icing model of total productive system of an industrial society is introduced. Second, this research introduces the challenge-creative response model of economic evolution and the societal innovation in different categories of society. Third, a three-tiered conceptual framework from an ordonomic perspective is presented. Fourth, the vantage point of the three-tiered ordonomic perspective and the societal innovations in different categories of society are formed into the ordonomic-societal innovations matrix in response to the game rule in human society. Fifth, this research delves into the cases of two eco-social enterprises: Neumarkter Lammsbraeu, a bio-pioneer in the production of organic beer, and Local Food Links and Wessex Reinvestment Trust, a local food community to illustrate the essence of ordonomic-societal innovations matrix from the viewpoints of economic growth paradigms. All in all, the article ends with a short summary and some concluding remarks.

\section{Keywords}

Eco-Social Enterprise, Societal Innovations, Ordonomic Perspective, Ordonomic-Societal Innovations Matrix

\section{Introduction}

\subsection{The World Economy Is Stagnating}

Quite simply, the economic condition of the world is unpleasant and terminal. The global economy, like a zom- 
bie, staggers half alive and half dead with its own special symptoms. The Great Economic Zombie may soon become extinct, diagnosed from a condition known as zero growth-economic stagnation. The Great Capitalism, which advocated on limitless growth that depended on consumption, is coming to an end.

In the modern economy, many terms are used to describe the limitless growth of economic growth paradigm such as unlimited growth, ever-lasting growth and infinite growth economic paradigm. Under the market-economics, the game played is to maximize their profit for shareholders with a globalizing structure. Under this structure, people are self-interested, rational, and competitive leading to further well-being from consumption. Those firms should focus only on profit and growth, which decreasing returns to scale will prevent monopoly power. Economies that best function with "free" markets, free trade, growth maximisation, deregulation, privatisation, globalisation...United Kingdom in 19th century and United States of American in 20th century are two century of limitless growth paradigm for triumph in the West.

However, in a global economic stagnation of the 21st century, people suddenly came to realization about the large sum of expenditure at the success of western-style modernization. Oliver Markley described five possible situations in the future, of which the second possibility is the future "Civilizational Disintegration", which depicts the last extremity of the limitless growth paradigm [1]-[3].

As early as 1970, the West has begun to understand the potential side effects of the limitless growth paradigm. Kenneth Boulding stated "Anyone who believes exponential growth can go on forever in a finite world is either a madman or an economist.” In 1972, Club of Rome appealed that the industrialization model of economic development in the limitless growth paradigm not only caused the sharp contradictions between mankind and nature, but humans would continue to be faced with nature's revenge. If the current rapid growth patterns of populations and capitals continue, the world will face a "catastrophic collapse". Thus, the best way to avoid this collapse is "zero growth", by implementing the two policies of "zero population growth" and "zero economic growth" [4]. In the early1980s, the United Nations established the Commission on sustainable development to advocate the limited growth of sustainable development of economic theory in an attempt to ease the positive and negative poles of economic hegemony of western-style modernization's achievement.

Utilized by the mainstream, the limited growth paradigm is advocated through the promotion of sustainable development by the United Nations. The Zero-growth paradigm proposed by the Club of Rome due to the nearly Great stagnation has recently gained world-wide attention. United Nations sustainable development discusses the rights in the economic sector, however the Club of Rome zero growth discussion will shift to the right of ecological sector. In fact, the proposed concept of zero economic growth radically denied the basis of sustainable development. During the First International Conference of Economic De-growth for Ecological Sustainability and Social Equity in 2008, degrowth paradigm became a great issue during the burst of the world financial crisis [5]-[9]. In reality, the terminating condition of Great Capitalism will allow the rebirth of a new, fresh economy.

\subsection{Research Goals, Hypothesis and Framework}

Social Enterprise emerged from the organizational failure/dysfunction (Governance Failure/Dysfunction, Market Failure/Dysfunction and Volunteer Failure/Dysfunction) from 1990 and was regarded as the antidote of failure/dysfunction of modern economy in the limitless growth paradigm. As OECD (1999) definition mentioned below, the OECD definition of social enterprise is "any private activity conducted in the public interest, organized with an entrepreneurial strategy but whose main purpose is not the maximization of profit but the attainment of certain economic and social goals, and which has a capacity of bringing innovative solutions to the problems of social exclusion and unemployment." Social enterprise tries to break the barrier among the sectors [10].

In the eve of $21^{\text {st }}$ century, triple bottom line that is referred to as "People, Planet, Profit" or "3BL"became widely popular. Authors move in tandem with this perspective because 3BL is discerned with the differences of the growth paradigms. The authors interest eSE (eco-social enterprise) in limited growth paradigm and degrowth paradigm more than eSE in limitless growth paradigm.

The aim of this study is to reframe the eco-social enterprise from different types of societal innovations in the human society. The argument was developed in five steps. First, the three-layer cake with icing model of total productive system of an industrial society is introduced. In this phase, a distinction between the market-capitals and non-market capitals are made followed by the extension of three kinds of economic growth paradigm, three types of economy with a focus on productive system.

The second step introduces the challenge-creative response model of economic evolution and the societal innovations in the different categories of the society. This research modifies Oliver Markley's and Otto Schar- 
mer's researches and distinguishes between the societal innovations of the desilience, resilience and consilience.

The third step introduces the three-tiered conceptual framework of the ordonomic perspective introduced by Ingo Pies et al. This research compares the discriminating factors between the basic game of value creation, metagame of entrepreneurial rule-setting, and meta-meta game of rule-finding discourse.

The fourth step then uses the three-tiered ordonomic perspective and the societal innovations in different categories of society that are formed for the ordonomic-societal innovations matrix in response to the game rule in human society to gain a more in-depth understanding.

At the final step, two case studies of eco-social enterprises were conducted-a bio-pioneer in the production of organic beer, Neumarkter Lammsbraeu, and a local food community, Local Food Links and Wessex Reinvestment Trust to illustrate the ordonomic-societal innovations matrix in different economic growth paradigms.

\section{Theoretical Background}

\subsection{Total Productive System of an Industrial Society}

Henderson's cake model [11]-[13] equates the monetized layer principally with the private and public sectors, and leads clear dividing lines between the monetized and non-monetized spheres in the total productive system of an industrial society. Furthermore, the cake model shows many relationships between economic growth paradigm, types of economy and types of focus on productive system (Figure 1).

In modern economy of the limitless growth, it focuses on the GNP-Monetized 1/2 of cake, top two layers, "Private Sector" impacts on "Public Sector" and it in turn impacts on "Social Cooperative Caring Economy" and it finally impacts on Nature's Layer in Hazel's three-layer cake with icing. However, many proponents of social enterprise, social investing, corporate social responsibility, and venture philanthropy subscribe to the double bottom line, which includes economic and social impact. Social enterprises mix market and the non-market products, balance of mission and market, and rise social and economic value creation as the antidote of failure/dysfunction of modern economy in the limitless growth paradigm.

In the cake model, Henderson claims the embeddedness of the green economy is of limited growth which focus on all of cake and that the private sector is actually dependent on the public sector, which is then dependent on the sweat-equity (core economy) that relies on the Mother Nature. This three-layer cake with icing model is furthered by the market, the public and the core economies which are all reliant on the economy of the Mother Nature layer. The Brundtland Commission at the United Nations (Brundtland, 1987) defines the development as "meeting the needs of the present without compromising the ability of future generations to meet their own needs" [14]. Moreover, the term "sustainability" has been established on a world-wide scale to denote the search for long-term solutions that help alleviate economic, ecological and social dimensions of societal problems. In the book Small is Beautiful, economist Schaumacher (1973) explained that "the modern private enterprise system ingeniously employs the human urges of greed and envy as its motive power" but then asks "Can such a system conceivably deal with the problems we are now having to face?” [15] The answer is self-evident as greed

\begin{tabular}{|c|c|c|c|c|}
\hline \multicolumn{2}{|c|}{ Economic growth paradigm } & Limitless growth & Limited growth & degrowth \\
\hline \multicolumn{2}{|c|}{$\begin{array}{l}\text { Total Productive System of an } \\
\text { Industrial Society } \\
\text { (Three-Layer Cake with Icing) }\end{array}$} & Modern economy & Green economy & Degrowth economy \\
\hline \multirow[t]{2}{*}{$\begin{array}{l}\text { GNP-Monetized } \\
1 / 2 \text { of Cake }\end{array}$} & Private sector & $\begin{array}{l}\text { GNP " Private "Sector } \\
\text { which impacts on }\end{array}$ & $\begin{array}{l}\text { GNP " Private "Sector } \\
\text { which rests on }\end{array}$ & $\begin{array}{l}\text { GNP " Private "Sector } \\
\text { which nests on }\end{array}$ \\
\hline & $\begin{array}{l}\text { Public Sector } \\
\text { Cash-based }\end{array}$ & $\begin{array}{l}\text { GNP " Public "Sector } \\
\text { which impacts on } \\
\downarrow\end{array}$ & $\begin{array}{l}\text { GNP “ Public "Sector } \\
\text { which rests on }\end{array}$ & $\begin{array}{l}\text { GNP "Public "Sector } \\
\text { which nests on }\end{array}$ \\
\hline \multirow[t]{2}{*}{$\begin{array}{l}\text { Non-Monetized } \\
1 / 2 \text { of Cake }\end{array}$} & Sweat-Equity & $\begin{array}{l}\text { Social Cooperative } \\
\text { Caring Economy } \\
\text { which impacts on }\end{array}$ & $\begin{array}{l}\text { Social Cooperative } \\
\text { Caring Economy } \\
\text { which rests on }\end{array}$ & $\begin{array}{l}\text { Social Cooperative } \\
\text { Caring Economy } \\
\text { which nests on }\end{array}$ \\
\hline & Mother Nature & Nature's Layer & Nature's Layer & Nature's Layer \\
\hline \multicolumn{2}{|c|}{$\begin{array}{l}\text { Hazel Henderson, Total Productive System of an Industrial } \\
\text { Society, } 1996 .\end{array}$} & & & \\
\hline \multicolumn{2}{|c|}{ Focus on Productive system } & $\begin{array}{l}\text { GNP-Monetized } \\
1 / 2 \text { of Cake } \\
\text { Top Two Layers }\end{array}$ & $\begin{array}{l}\text { All Three-Layer } \\
\text { Cake with Icing }\end{array}$ & $\begin{array}{l}\text { Non-Monetized } \\
\text { Productive } 1 / 2 \text { of Cake } \\
\text { Lower Two Layers }\end{array}$ \\
\hline
\end{tabular}

Figure 1. Mixed economic growth paradigm in three-layer cake with icing model. 
and envy demand continuously on the limitless material economic growth. Without proper regard for conservation, this type of growth cannot possibly fit into a finite environment. The study of nature in the private enterprise system and the possibilities of evolving an alternative system, which might fit the new situation, are quintessential.

The Mother Nature level has become slightly more visible from a mainstream economic perspective in the recent decades but efforts to quantify the economy of nature (and thus to bring its "non-market products" into the orthodox economics field of vision) are with limited success [16].

In the degrowth economy, which focus on lower two layers, non-monetized productive $1 / 2$ of cake, the private sector nests on public sector and then nests on Social Cooperative Caring Economy. Then, it nests on Nature's Layer in Hazel's cake model. Reid and Griffith (2006) suggested that potential eco-social enterprises have to tackle the quadruple bottom line as well as nesting of economic, social, ecological and community concerns concurrently. Each of them should receive equal weight in evaluating the success of an eco-social enterprise. They contend that eco-social enterprises not only promote economic development but also improve social capital, equality and community development [17]. Eco-social entrepreneurs should mirror magicians to bring thrivability, innovation and social transformation. For the purpose of this paper, we define eco-social enterprise as an organization that comprises a clear social, cultural and/or environmental purpose, primarily rooted in serving the local community and ideally having a local and/or democratic ownership structure. When an eco-social enterprise serves another social enterprise rather than serving the needs of the public directly, this research suggests the term "secondary eco-social enterprise".

\subsection{Societal Innovations in Different Categories of Society}

An entrepreneurial strategy is a simplified strategic framework designed for smaller companies, particularly for innovators wishing to "get to the next level". The strategy should be designed to help entrepreneurs identify and strengthen their firm's unique offering as well as maximizing their revenues. The above entrepreneurial strategy is adequate for a social enterprise in the modern economy. But at the turn of the $21^{\text {st }}$ century, new forms of organization with different essences are emerging across various sectors with the intertwined complicated problems in the global context. Such complicated problems embody both detailed complexity of order and dynamic complexity of Chaos. Since the emergence of eco-social enterprise focused on green economy or degrowth economy, have the seemingly contradictory organizational embodiments that is worthy of our further inquiry of its evolutionary phases.

The edge of chaos balances on the egde between periodic and chaotic behavior as well as of instability with order. The edge of chaos is characterised by developed structure over many different scales and is an often found feature of those complex systems whose parts have some freedom to behave independently.

In Oliver Markley's research, it is based on the "Aspirational Futures Method" pioneered by Clem Bezold (2009) that stated the expected (PTE), challenging (fearful), aspirational (hopeful), and audaciously aspirational (visionary) to describe the five scenarios of the edge of chaos [18].

(1) VUCA (Volatility, Uncertainty, Complexity, and Ambiguity)—an "Expected" or "Present Trends Expected" (PTE) future;

(2) Civilizational Disintegration—a "Challenging" or worst-case future;

(3) Reformative Civilizational Recovery—an "Aspirational” (Visionary) future;

(4) Civilizational Enlightenment—an "Audaciously Aspirational” future;

(5) Singularity—a second "Audaciously Aspirational” future.

Depending on the five scenarios of the edge of chaos, there are three main scenarios in the edge of chaos: (1) desilience (disintegration - a "challenging" or worst case future), which is equal to the condition of limitless growth paradigm, we will name it society of desilience; (2) resilience (recovery—an "Aspirational, Visionary" future), which is equal to the condition of limited growth paradigm, we will name it society of resilience; and (3) consilience (enlightenment—an "Audaciously Aspirational” future), which is equal to the condition of degrowth paradigm, we will name it society of consilience (Figure 2).

In the book of Scharmer \& Kaufer (2013), they introduced the idea of the challenge-creative response model of economic evolution and the societal innovations in four categories of society [19]. They thought:

Society 1.0: Organizing around hierarchy

This involves organizing around hierarchy and central planning, giving rise to centralized economies (socialism, mercantilism), and embodying the traditional forms of values and awareness. The state-centric model is characterized by coordination through hierarchy and control in a single-sector society. This occurs when there is 


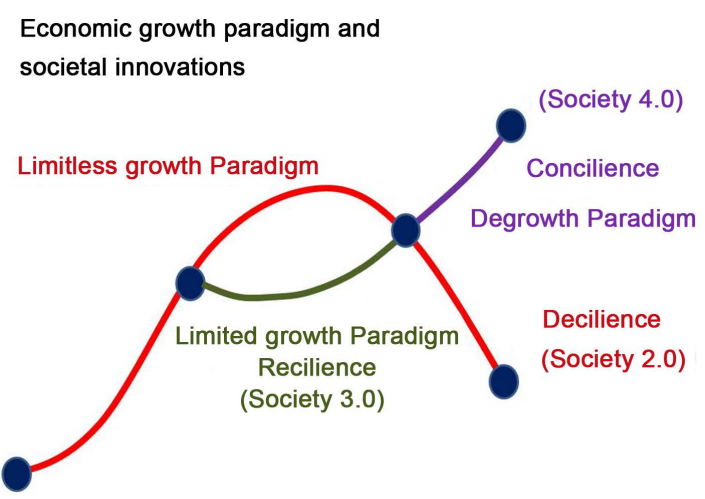

Figure 2. Economic growth paradigm and societal innovations.

violence, insecurity, hunger...One actor (emperor, tzar, party) governs the whole thing with an iron fist to provide security along with the vital allocation of scarce resources in line with much-needed public infrastructure investment. Good for stabilizing when there is chaos and instability but gives no opportunities for entrepreneurship.

Society 2.0: Organizing around competition

Organizing around competition involves organizing around markets and competition, incrementing to the second (private) sector, the free market economy. This embodies the state of ego-system awareness, concerning for the well-being of oneself. After a society has met their stability goal, they want to grow. The free-market model is characterized by raising the second (private) sector, coordinating through the mechanisms of market and competition. The maximization of self-interest thinking, economic growth, wealth, entrepreneurship also produces negative externalities. There is a shift to individual freedom and initiative that unfortunately lead to negative externalities as a result.

Society 3.0: Organizing around interest groups

Organizing around interest groups involves organizing around stakeholder negotiations and dialogues, giving a raise to the third (social) sector and the social market economy (stakeholder capitalism). This embodies the state of stakeholder awareness, that is, a concerning for the well-being of oneself and one's immediate stakeholders. The social-market model is characterized by the rise of a third (NGO) sector through negotiated coordination among some key organized interest groups. Institutional innovation, social security, labor and environment standards, regulation of the financial system with special interests of some minorities overcome everyone else. Although special interest groups and NGOS deal decently with some externalities, they often fail to react in a timely manner to global challenges. For other negative externalities, their solutions become invalid.

Society 4.0: Organizing around the emerging whole

This involves organizing around awareness based collective action (ABC) as a mechanism to transform stakeholder relationships from habitual to co-creative. This way of operating embodies eco-system awareness, that is, a concern for the well-being of other stakeholders and the whole. The co-creative eco-system model is characterized by the rise of a fourth sector that creates platforms and holds the space for cross-sector innovation which engages stakeholders from all sectors to participate in the well-being of the whole. Global disruptive externalities are the primary societal challenge. Awareness-based collective action is its creative response. The hero of the common people co-create between civil society and NGOs and start actions that arise from seeing the emerging whole.

In this paper, we consider that society of desilience is society 2.0, the society of resilience, society 3.0 and the society of consilience, society 4.0 .

In the desilience phase of limitless growth paradigm, the societal innovation in society of desilience is a free-market-driven, Laissez-faire economy, and the players maximize individual profit for business shareholders under a globalizing structure.

In the resilience phase of the limited growth paradigm, the societal innovations in society of resilience is a stakeholder-driven, social-market economy, and the players maximize public justice and create values for society stakeholders in a localizing structure.

In the consilience phase of degrowth paradigm, the societal innovations in society of consilience is an eco- 
system driven, co-creative economy. The players then maximize the complete meaning and make goodness for living being in a localizing structure.

\subsection{The Three-Tiered Conceptual Framework of the Ordonomic Perspective}

The three-tiered conceptual framework of the ordonomic perspective includes basic game, metagame and meta-meta game. Basic game asks and tries to define behavior patterns, what drives patterns, organization structure, processes, and information systems, etc. Meta game asks and tries to define social structures such as what allows structures to persist and the values, beliefs and goals that shape the social structure. Meta-meta game asks and tries to define mental models.

The basic game assumption of ordonomics is that players' decisions, envisions and interactions are not solely influenced by their desires, needs or their behavior patterns but depends systematically on the social structure they are embedded in [20]-[23]. From an ordonomic view, the different interaction outcomes of the basic game are critical. Whether the result of the interactions is desirable or undesirable, rather than owing to personality, it stems from the social structural in views of the complexity embedded in the social relations of interdependence. It is the social structure, process, the quality of information and the incentive properties of the rules in the game that systematically determines the game's consequence [24].

According to ordonomics, "social structure" is defined as formal and informal institutional arrangements such as organization structure, processes, information systems, which are the result of a longstanding evolutionary process. From an ordonomic perspective, the concept of the social dilemma is crucial for understanding how entrepreneurs set free new potentials for social value creation in the social structure [25] [26]. Technically, a "social dilemma" refers to a situation in which rational actors fail to realize their common interests due to their conflicting individual interests. There are many well-known examples of collective self-damage, including the "tragedy of the commons" [27], collective-action problems and corresponding "free-riding" issues [28].

Two typical type dilemmas of ordonomic structures include the structure of one-sided and many-sided. One-sided dilemma structure allows a single player to change the basic rules of the game. On the other hand, many-sided dilemma structure finds that the majority of cases when involved competition, depend on all players to participate in the rule-making process, even if they were antagonists in the basic interactive games [29].

Ordonomics argues that the process of social structure's evolution depends largely on mental models. Mental model is in relatedness to individuals, collective groups, self-image, schema, frame, mental processes and mindscope, etc. Hence, it can also be pertinent to collective unconsciousness, gene, culture Meme, civilizational unconsciousness, global consciousness, or paradigm.

Mental models are important in this regard because voluntary collaboration and collective impacts between players is largely dependent on how they sense, presence and realize. From an enterprise architecture and change-management perspective, mental model is important because it channels processes about social structures in particular to social behavioral patterns about social interactions, conflict and cooperation.

Of note, we can state that the basic concern of the ordonomic research program is in need of a systematic idealized design of interdependencies between behavioral patterns and events. In essence, it is the analysis of interdependencies between "social structure" and "mental models."

\section{Framework: Ordonomic-Societal Innovations Matrix}

Theoretically, ordonomic perspectives * societal innovations, we get ordonomic/societal innovations matrix (Figure 3).

\subsection{Basic Game * Societal Innovations}

The first level describes the basic game of social interaction in the community and within the organization. The daily interactions related to the basic game, not only in the place in the market and companies and other organizations, but also in the political, sports, science, and other areas of society. In these environments, basic social game of individual players pursues their own goals, and responds to incentives and opportunities to each other [30]-[32].

In the desilience phase of limitless growth paradigm, the societal innovations in society of desilience is a free-market-driven, Laissez-faire economy, and the players maximize individual profit for business shareholders 


\begin{tabular}{|c|c|c|c|c|c|}
\hline \multirow{5}{*}{$\begin{array}{l}\text { Framework: } \\
\text { Ordonomic- } \\
\text { Societal } \\
\text { Innovation } \\
\text { Matrix }\end{array}$} & \multirow{2}{*}{ 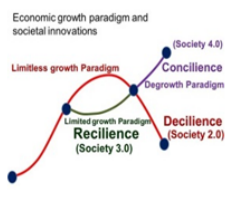 } & $\begin{array}{l}\text { Economic } \\
\text { Society }\end{array}$ & $\begin{array}{l}\text { Society of } \\
\text { Desilience }\end{array}$ & $\begin{array}{l}\text { Society of } \\
\text { Resilience }\end{array}$ & $\begin{array}{l}\text { Society of } \\
\text { Consilience }\end{array}$ \\
\hline & & $\begin{array}{l}\text { Societal } \\
\text { Innovation }\end{array}$ & $\begin{array}{l}\text { Organizing around } \\
\text { Competition }\end{array}$ & $\begin{array}{l}\text { Organizing around } \\
\text { Interest Groups }\end{array}$ & $\begin{array}{l}\text { Organizing around } \\
\text { the Emerging Whole }\end{array}$ \\
\hline & \multirow{3}{*}{ 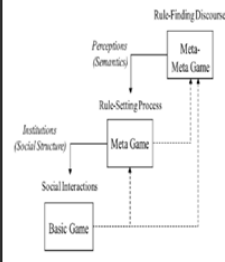 } & $\begin{array}{l}\text { Meta-meta } \\
\text { Game }\end{array}$ & $\begin{array}{l}\text { Profits for Business } \\
\text { Shareholder }\end{array}$ & $\begin{array}{l}\text { Value for Society } \\
\text { Stakeholder }\end{array}$ & $\begin{array}{l}\text { Goodness for } \\
\text { Living Being }\end{array}$ \\
\hline & & Meta Game & $\begin{array}{l}\text { Globalizing } \\
\text { Structure }\end{array}$ & $\begin{array}{l}\text { Glocalizing } \\
\text { Structure }\end{array}$ & $\begin{array}{l}\text { Localizing } \\
\text { Structure }\end{array}$ \\
\hline & & Basic Game & $\begin{array}{l}\text { Maximize } \\
\text { Individual Profit }\end{array}$ & $\begin{array}{l}\text { Maximize Public } \\
\text { Justice }\end{array}$ & $\begin{array}{l}\text { Maximize Whole } \\
\text { Meaning }\end{array}$ \\
\hline
\end{tabular}

Figure 3. Ordonomic-societal innovations matrix.

under a globalizing structure. In the basic game, they maximize profits with ambitions and competitions and shift the side effects, unintended consequences as externality.

In the resilience phase of the limited growth paradigm, the societal innovations in society of resilience area stakeholder-driven, social-market economy with reciprocity and love of humanity. The players maximize public justice and create values for society stakeholders in a localizing structure. In the basic game, they maximize public justice with passion and compassion, reducing side effects that are unintended of the internality consequences.

In the consilience phase of degrowth paradigm, the societal innovations in society of consilience is an ecosystem driven, co-creative economy with strong reciprocity for all sentient beings. The players maximize the complete meaning and make goodness for living in a localizing structure. In the basic game, they maximize whole meaning with presensing and co-realizing, neutralize the side effects as unintended consequences of coternality.

From an ordonomic view, the courses of the different growth paradigms of the basic game descriptions have no interoperability even among the limited growth and degrowth paradigm. Passion and compassion are uncertain formulas for business success in limitless growth paradigm [29]. Social or eco-social entrepreneurs, who find themselves under pressure from market competition, depend crucially on the level at which the passion and compassion are brought into play. In the iron rule world- "eye for eye, tooth for tooth", there are no space for the altruism. Contrarily, in the "golden Rule" world-“For everything, do to others as you would have them do to you", passion and compassion are of great advantage and really a certain formula for business success in limited growth paradigm.

\subsection{Meta Game* Societal Innovations}

This meta game concerns those processes of enterprise architecture's rule-setting by which the players establish the social structures that can help reshape the behavior patterns of the basic game. It serves to redesign and reform institutions in order to set organizational vision. Thus, it possesses the leverage to redesign change and manage the social structure that navigates the interactions in the basic game. Furthermore, if the basic game produces unintended social side effects, it is the meta game that enlarges the possibility for changing the generally unseen situation into a visible one that is mutually advantageous.

In the desilience phase of limitless growth paradigm, the societal innovations in society of desilience is a free -market-driven, laissez-faire economy, and the players maximize individual profit for business shareholders under a globalizing structure. In the meta game, they maximize profit in globalizing structure based on economy. Corporation action dominates personal action. Players are involved in the whirlpool of escalation, falling into eternal vicious loops.

In the resilience phase of the limited growth paradigm, the societal innovations in society of resilience is a stakeholder-driven, social-market economy, with reciprocity and the love of humanity and the players maximize public justice and create values for society stakeholders in a localizing structure. In the meta game, the players maximize justice in localizing structure based on society. Group action compassionates personal passion action. Players must deal with "free-rider problems" or "tragedy of the commons", struggling in the dark side of human nature. 
In the consilience phase of degrowth paradigm, the societal innovations in society of consilience is an ecosystem driven, co-creative economy, by altruistic punishment or strong reciprocity for all sentient beings. The players maximize whole meaning and make goodness for living being in a localizing structure. In the meta game, the players maximize whole meaning in localizing structure based on ecology. Community action is dominated by personal action. Players must deal with matters of difficult challenges, enduring merciless retaliation of nature.

\subsection{Meta-Meta Game * Entrepreneuring Strategy}

As mentioned above, individual players make very few games-changing to cater to their desirable interaction. In many cases, the institutional framework must embed collective action, requiring the voluntary cooperation of the different players. However, the ordonomics perspective based on rational choice theory assumes that players will never agree to reform and cooperation unless they understand and agree that these new rules will be good for each of them separately. Therefore, the recognition of common interests is an important condition for reform [29].

Similar to situational envision of the social structure shaping individual behavior patterns, the mental model as the intellectual order of ideas is a frame that shapes our values and beliefs. Discourses are vital to issues relating to the definition and development of common interests. To address these issues in the economic, social and environmental aspects of common understanding is crucial.

In the desilience phase of limitless growth paradigm, societal innovations in the society of desilience consist of a free-market-driven, Laissez-faire economy. Hence, the players maximize individual profit for business shareholders under a globalizing structure. In the meta-meta game, the players maximize profit in globalizing structure and make profits for business shareholders.

In the resilience phase of the limited growth paradigm, the societal innovations in society of resilience are a stakeholder-driven, social-market economy, with reciprocity and the love of humanity. The players maximize public justice and create values for society stakeholders in a localizing structure. In the meta-meta game, the players maximize justice in localizing structure and creating values-fraternity, equality and sustainability for society stakeholders.

In the consilience phase of degrowth paradigm, the societal innovations in society of consilience is an ecosystem driven, co-creative economy, by altruistic punishment or strong reciprocity for all sentient beings, and the players maximize whole meaning and make goodness for living being in a localizing structure. In the metameta game, the players maximize whole meaning in localizing structure and make goodness-fraternity, equality and thrivibility for humanity.

The third level of social interaction prompts such awareness as this meta-meta game serves as an arena for rule-finding discourse. On the other hand, the meta game focuses on institutions. In other words, in the social structure, the meta-meta game is focused on the importance of ideas-the mental model.

\section{Methodology: Case Study Analysis}

\subsection{Neumarkter Lammsbraeu: A Case of Resilience Strategy}

The founder of Neumarkter Lammsbraeu, Dr. Franz Ehrnsperger, is regarded as a remarkable eco-social entrepreneur. Neumarkter Lammsbraeu is German brewery with more than 30-year history of brewing organic beer. Thus, it is a change-maker of the sustainable development in Germany.

In the resilience phase of the limited growth paradigm, the societal innovation in society of resilience is a stakeholder-driven, social-market economy, with reciprocity and the love of humanity and the players maximize public justice and create values for society stakeholders in a localizing structure. Following his envision that "ecology is long-term economy”, Ehrnsperger believes that entrepreneuring an organic brewery according to reciprocity would create a win-win outcome for all stakeholders. By providing consumers with high-quality products, all stakeholders can be winners as employees are provided with rewarding jobs, local farmers with a long-term demand for locally produced organic raw materials [29].

In the basic game, the players maximize justice with passion and compassion, which reduce side effects, unintended of the consequences. 
Limited growth-driven eco-social entrepreneurs often show high levels of passion and compassion that maximize justice towards their stakeholders in their environmental concerns. Furthermore, they try to reduce the side effects, which is regarded as unintended consequences of internality.

As early as 1980, Ehrnsperger was already driven by a passionate vision of creating an economically, socially and ecologically sustainable brewery business according to his reciprocity principles. The intension, envision and realization of his passion was driven early on by compassion for his stakeholders keen to take responsibility for local farmers. This is an example of how passion and compassion can change the way stakeholders interact in the basic game. Transforming the passion for his corporate vision into an individual self-commitment, Ehrnsperger offered his farmers long-term contracts with a guaranteed contract of five years. These compassionate self-commitment strategies of Ehrnsperger in Neumarkter Lammsbraeu truly changed the interactions between the brewery and the farmers [29].

In the meta game, the players maximize justice in localizing structure based on society. Players must deal with "free-rider problems" or "tragedy of the commons", struggling in the dark side of human nature.

Passion and compassion can play a vital role in these meta games because group action compassionates personal passion action in a win-win world. Passion and compassion can help establish functional commitments to foster functional commitments services to overcome undesirable social dilemmas like "free-rider problems" or "tragedy of the commons". In Neumarkter Lammsbraeu, Ehrnsperger presented win-win solutions, but also implanted them by incorporating passion and compassion through institutional innovations that actually redesign and reform the basic game of value creation by changing the rules of the game [29]. In 1988, Neumarkter Lammsbraeu initiated the "Erzeuger Zusammenschluss fürOekologische Brauereirohstoffe" (EZOEB) and required all then organic contract farmers to join this association. The EZOEB is an important institutional innovation that solved "free-rider problems" and "tragedy of the commons" that were keeping the eco-social enterprise from meeting its full potential. Farmers can now cooperate with other farmers through the EZOEB in keeping high standards for maximizing justice in localizing structure based on society. Providing this compassionate service with collective self-commitment, this is proven to be a change-maker in favor of sustainable development.

In the meta-meta game, the players maximize justice in localizing structure and value creation-fraternity, equality and sustainability for stakeholders in the society.

Ehrnsperger understands that passion and compassion in the meta-meta game of rule-finding discourse could lead to a fully sustainable impact on the meta game and basic game. The focus on value creation then transforms into a constructive rule-setting meta game to change rules of the game in a way that produces a mutually advantageous social structure. Hence, a constructive rule-finding meta-meta game can generate great values for society stakeholders. It is also acknowledged that the concept of functional commitments helps to understand on how eco-social entrepreneurs can transform a passionate and compassionate win-win orientation into better rules of the game in the limited growth paradigm. In Neumarkter Lammsbraeu, such functional commitments are institutional innovations in the meta game and meta-meta game because it is beneficial to direct the power of passion and compassion towards the meta-meta game of rule-finding and the meta game of rule-setting [29]. He aimed to improve the governance structure of economic behavior, passion and compassion of behavioral patterns that can provide powerful win-win heuristics for creating untapped potentials for value creation stakeholders in the society. It is shown that such win-win institutional innovations could reframe social dilemmas that resonate with passion and compassion into sustainable win-win scenarios by redesigning the rules of the game.

\subsection{Local Food Links and Wessex Reinvestment Trust: A Case of Consilience Strategy}

The West Dorset Food \& Land Trust, Local Food Links and Wessex Reinvestment Trust in South West England were founded by a group of practitioners. These practitioners are active in fields such as local food systems, affordable housing and renewable energy. Such fields are linked together through their involvement in the Wessex Reinvestment Trust group.

In the consilience phase of degrowth paradigm, the societal innovation in society of consilience is an ecosystem driven, co-creative economy, through altruistic punishment or strong reciprocity for all sentient beings. The players maximize the collective meaning and make goodness for living in a localizing structure.

Mainstream view of firms' core purpose is to maximise profits for shareholders, and financial considerations more important than social or environmental considerations. One of the practitioners Tim Crabtree (2010) in- 
sisted that economic institutions could be subordinated into 3 key principles [33]:

-Direct and participative democracy in the economy (control by producers, consumers or community, or a combination of the 3);

-Environmental sustainability (meeting the needs of the present generation without compromising the ability of future generations to meet their own needs);

-Social justice (including equality of opportunity and redistribution of wealth).

In this ideal community, there are no-win-no-lost and rule by altruistic punishment or strong reciprocity for all sentient beings.

In the basic game, the players maximize meaning with presensing and co-realizing, neutralize the side effects, unintended consequences as co-ternality.

Tim Crabtree (2010) followed the Professor Kevin Morgan's indication: "the multifunctional character of the food system means that it has profound effects on a host of other sectors-including public health, social justice, energy, water, land, transport and economic development” [33]. He advocated local economic alternatives and food as an inception point because food is equal to everything. Food systems are complex, connected to economy, society, environment and individual well-being. Can we design alternative economic systems that operate within environmental and social boundaries? What design principles can we use to create eco-social enterprises that contribute to a sustainable, high well-being and socially-just economy? What is the core purpose of this eco-social enterprise? He worked out with sensing, presencing and realizing to let everyone (1) understand the rationale for "alternative" local economic systems, and the problems associated with globalised economic systems, using food as a focus for the analysis; (2) understand the impacts of environmental limits on economic systems, and explain the social, economic and environmental benefits of activity at a local level; (3) understand the key features of "alternative" eco-social enterprises-including organisational structures, financing, operations, ethos, the role of collaboration [33]. He asked a group of practitioners to go in-depth to define their most fundamental beliefs, co-sense, co-presence and then co-realize with those beliefs. Through this kind of deep questioning, they rediscover abundant living, neutralize the side effects, and regard unintended consequences as co-ternality in a harmonious natural world.

In the meta game, the players maximize meaning in localizing structure based on ecology. Community action is dominated by personal action. Players must deal with matters of difficult challenges, enduring merciless retaliation of nature.

Instead of imagining a spectrum, from non-profit/public benefit to for-profit/private benefit and deciding where to place oneself on that spectrum, Tim Crabtree (2010) stated that it is possible to envisage local and regional economic systems [33]. It is entailed with a combination of structures, which operate along that spectrum-from trusts to private enterprises. The meaning of localizing structure is based on ecology that community action is dominated by personal action within a democratic enterprise.

In Local Food Links, schools, parents and seniors could become members. They could provide investment, volunteer assistance or sit on the committees. Collaboration between organisations in a local/regional area is a potential method of overcoming the range of difficulties faced by community food enterprises. However, collaboration is not easy; it involves dealing with an increased level of complexity. It may require co-operation between individuals and organisations with divergent motivations. Moreover, It is subjective to resource constraints: time and money that is carried out in a context of competition from large-scale organisations to enable influence on the rules to ensure "success to the successful" [33].

Together, they try hard to deal with matters of difficult challenges, enduring merciless retaliation of nature.

In the meta-meta game, the players maximize meaning in localizing structure and make goodness-fraternity, equality and thrivibility for all sentient beings.

The local food economy, like a community-food enterprise can be thought of as a nested system. Tim Crabtree traced back to the sources and deferred to Meadows [34], "Systems can be embedded in systems, which are embedded in yet other systems."

One way to think about these new economic systems is in terms of three levels of activity. This is in recognition that the provision of goods and services need to be underpinned by secondary business structures, and also by trusteeship or "open source", commons-based mechanisms [35]:

Level 1: Direct provision of goods and services which meet local needs by Local Food Links;

Level 2: Provision of secondary business services, in order to underpin the provision of goods and services by 
Bridport Centre for Local Food;

Level 3: Underpinned by access to finance from Wessex Reinvestment Trust, the embedding, wherever possible, of the 4 key "factors of production"-land, labor, capital and knowledge-in non-marketized frameworks, ensured their availability for, and interaction with, levels $1 \& 2$.

Woven into the fabric of the level 1, 2 and level 3, they devoted themselves to maximize meaning in localizing structure and thrivibility for all sentient beings.

\section{Conclusion: A Small Goodness Community}

For the case of Neumarkter Lammsbraeu, institutional innovations have transformed not only the brewery itself but also the entire supply chain and its local environment. The Neumarkter Lammsbraeu case also illustrates the entrepreneurial side of eco-social entrepreneurship. Entrepreneurial innovation is not about playing a given game better; it is about playing better games. In each of the situations discussed above, Neumarkter Lammsbraeu not only tried to optimize its individual moves within a given game, it also changed the rules of the game leading to achieving win-win outcomes for all stakeholders.

For the case of Local Food Links and Wessex Reinvestment Trust, Tim Crabtree and a group of practitioners have been engaged in the evolution of an alternative local economy, based on the idea that the economy should be embedded in social and environmental realities, such as fraternity, equality and thrivibility for all sentient beings.

In this new dimension, it tries to seek out creative people and engages them in spontaneous, deep dialogues. Currently, there is in great need of a deep dialogue in the limitless growth paradigm, limited growth paradigm and degrowth paradigm. It is through the exchanges of the mental model that we can be empowered to enable to us foresee the future with greater clarity.

Dao De Jing stated "Let there be a small country with few people: their food, sweet to them; their clothes, beautiful to them; their homes, comfortable to them; and their customs, joyful to them.” To Laozi, this ideal country would be small, isolated, and simplicity. If there is a continuing growth of in-depth dialogues of collective efforts within and across eco-social enterprises, this ideal can change the mainstream of the future economy.

\section{References}

[1] Markley, O.W. (2011) A New Methodology for Anticipating STEEP Surprises. Technology Forecasting \& Social Change, 78, 1079-1097.

http://www.imaginalvisioning.com/wp-content/uploads/2010/08/Anticipating_STEEP_Surprises-TFSC1.pdf

[2] Markley, O.W. (2011) Research and Action toward the Upside of Down. Journal of Futures Studies, 15, No. 3. http://www.jfs.tku.edu.tw/15-3/E01.pdf

[3] Markley, O.W. (2011) Manifesting Upside Recovery Instead of Downside Fear: Five Ways Mega Crisis Anticipation Can Proactively Improve Futures Research and Social Policy. Journal of Futures Studies, 16, 123-134.

[4] Meadows, D., Randers, J., and Meadows, D. (2004) Limits to Growth: The 30-Year Update. White River Junction, Chelsea Green, VT.

[5] Latouche, S. (2009) Farewell to Growth. Polity Press, Cambridge.

[6] Latouche, S. (2010) Degrowth. Journal of Cleaner Production, 18, 519-522. http://dx.doi.org/10.1016/j.jclepro.2010.02.003

[7] Martínez-Alier, J., Pascual, U., Vivien, F.-D. and Zaccai, E (2010) Sustainable De-Growth: Mapping the Context, Criticisms and Future Prospects of an Emergent Paradigm. Ecological Economics, 69, 1741-1747. http://dx.doi.org/10.1016/j.ecolecon.2010.04.017

[8] Schneider, F., Kallis, G. and Martinez-Alier, J. (2010) Crisis or Opportunity? Economic Degrowth for Social Equity and Ecological Sustainability. Journal of Cleaner Production, 18, 511-518. http://dx.doi.org/10.1016/j.jclepro.2010.01.014

[9] Schriefl, E., Exner, A., Lauk, C. and Kulterer, K. (2008) On the Way towards a De-Growth Society: A Review of Transformation Scenarios and Desirable Visions of the Future. Proceeding of the First International Conference of Economic De-Growth for Ecological Sustainability and Social Equity, Paris, 18-19 April 2008, 258-268.

[10] OECD (1999) Social Enterprise. OECD, Paris.

[11] Henderson, H. (1996) Building a Win-Win World. Berrett-Koehler, San Francisco, 56.

[12] Henderson, H. (1999) Beyond Globalization: Shaping a Sustainable Global Economy. Kumarian Press, Connecticut. 
[13] Henderson, H. (2007) Ethical Markets Growing: The Green Economy. Chelsea Green, White River Junction.

[14] Brundtland, G.H. (1987) Our Common Future: Report of the World Commission on Environment and Development. Geneva, UN-Dokument A/42/427. http://www.un-documents.net/ocf-ov.htm

[15] Schumacher, E.F. (1973) Small Is Beautiful: Economics as If People Mattered. Harper \& Row, New York.

[16] Kutátek, S. (2009) Theories of Externalities and Their Application on Selected Segment of Transport. Faculty of Economics and Administration, Masaryk University, Brno.

https://www.is.muni.cz/auth/th/11271/esf_d/DIZERTACE_Kutacek_velka-obhajoba.pdf?fakulta1/41423;obdobi1/4478 4

[17] Reid, K. and Griffith, J. (2006) Social Enterprise Mythology: Critiquing Some of the Assumptions. Social Enterprise Journal, 2, 1-10. http://dx.doi.org/10.1108/17508610680000709

[18] Bezold, C. (2009) Aspirational Futures. Journal of Futures Studies, 13, 81-90.

[19] Scharmer, C.O. and Kaufer, K. (2013) Leading from the Emerging Future: From Ego-System to Eco-System Economies. Berrett-Koehler, San Francisco.

[20] Pies, I. (2007) Markt versus staat?_-Über Denk-und Handlungsblockaden in Zeiten der Globalisierung. In: Graf Ballestrem, K., Gerhardt, V., et al., Eds., Politisches Denken, Jahrbuch 2006/2007, Duncker \& Humblot, Berlin, 259-293.

[21] Pies, I., Beckmann, M. and Hielscher, S. (2010) Value Creation, Management Competencies, and Global Corporate Citizenship: An Ordonomic Approach to Business Ethics in the Age of Globalization. Journal of Business Ethics, 94, 265-278. http://dx.doi.org/10.1007/s10551-009-0263-1

[22] Pies, I., Beckmann, M. and Hielscher, S. (2011) Competitive Markets, Corporate Firms, and New Governance-An Ordonomic Conceptualization. In: Pies, I. and Koslowski, P., Eds., Corporate Citizenship and New Governance. The Political Role of Corporations (Ethical Economy), Springer, Dordrecht, 171-188.

[23] Pies, I., Beckmann, M. and Hielscher, S. (2014) The Political Role of the Business Firm: An Ordonomic Concept of Corporate Citizenship Developed in Comparison with the Aristotelian Idea of Individual Citizenship. Business and Society, 53, 226-259. http://dx.doi.org/10.1177/0007650313483484

[24] Popper, K.R. (1966) The Autonomy of Sociology. In: Popper, K.R., Ed., The Open Society and Its Enemies. Volume 2: Hegel and Marx, Harper, New York, 89-99.

[25] Petrick, M. and Pies, I. (2007) In Search for Rules That Secure Gains from Cooperation: The Heuristic Value of Social Dilemmas for Normative Institutional Economics. European Journal of Law and Economics, 23, 251-271. http://dx.doi.org/10.1007/s10657-007-9014-x

[26] Buttkereit, S. and Pies, I. (2008) Social Dilemmas and the Social Contract. In: Conill, J., Lütge, C. and SchönwälderKuntze, T., Eds., Corporate Citizenship, Contractarianism and Ethical theory, Ashgate Publishing, London, 135-147.

[27] Hardin, G. (1968) The Tragedy of the Commons. Science, 162, 1243-1248. http://dx.doi.org/10.1126/science.162.3859.1243

[28] Olson, M. (1965) The Logic of Collective Action. Harvard University Press, Cambridge.

[29] Beckmann, M., Pies, I. and von Winning, A. (2012) Passion and Compassion as Strategy Drivers for Sustainable Value Creation: An Ordonomic Perspective on Social and Ecological Entrepreneurship. Economic and Environmental Studies, 12, 191-221.

[30] Becker, G.S. (1976) The Economic Approach to Human Behavior. University of Chicago Press, Chicago.

[31] Becker, G.S. (1993) Nobel Lecture: The Economic Way of Looking at Behavior. Journal of Political Economy, 101, 385-409. http://dx.doi.org/10.1086/261880

[32] Coleman, J.S. (1990) Foundations of Social Theory. Harvard University Press, Cambridge.

[33] Crabtree, T. (2010) Stirring's Paper in Second Conference on Economic Degrowth for Ecological Sustainability and Social Equity, Barcelona, 26-29 March 2010. http://www.barcelona.degrowth.org/uploads/media/Tim-Crabtree-WG3-social-economy.pdf

[34] Meadows, D.H. (2008) Thinking in Systems: A Primer. Chelsea Green Publishing, White River Junction.

[35] Johanisova, N., Crabtree, T. and Frankova, E. (2013) Social Enterprises and Non-Market Capitals: A Path to Degrowth? Journal of Cleaner Production, 38, 7-16. http://dx.doi.org/10.1016/j.jclepro.2012.01.004 